\title{
Comparison of the Therapeutic Efficacy of Diclofenac Sodium and Methyl Salicylate Phonophoresis in the Management of Knee Osteoarthritis
}

\author{
Diz Osteoartritinin Tedavisinde Diklofenak Sodyum Fonoforezi ile Metil Salisilat \\ Fonoforezinin Terapötik Etkinliklerinin Karşılaştırılması
}

\author{
Sunday AKINBO, ${ }^{1}$ Oluwatoyosi OWOEYE, ${ }^{1}$ Sunday ADESEGUN ${ }^{2}$ \\ ${ }^{1}$ Department of Physiotherapy, College of Medicine, University of Lagos, Nigeria; \\ ${ }^{2}$ Department of Pharmacognosy, College of Medicine, University of Lagos, Nigeria
}

\begin{abstract}
Objectives: This study aims to investigate and compare the effectiveness of diclofenac sodium phonophoresis (DSPH), methyl salicylate phonophoresis (MSPH) and conventional therapeutic ultrasound (TUS) in patients with knee osteoarthritis (OA).

Patients and methods: Forty-five patients (8 males, 37 females; mean age 57.5 years; range 51 to 64 years) were included in this study between October 2008 and June 2009 and randomly assigned to three groups: DSPH, MSPH and TUS. Ultrasound waves of $1 \mathrm{MHz}$ frequency and 1 watts $/ \mathrm{cm}^{2}$ were applied to the target knee with either of two topical pain relieving gels as a coupling medium. Acoustic gel without any active pharmacological agent was applied in the TUS group. Ten treatment sessions were performed in all patients in the three groups. Western Ontario McMaster University Osteoarthritis Index (WOMAC) scores, 20-meter walking time and knee range of motion (ROM) were evaluated before and after the treatment using paired t-test and analysis of variance (ANOVA).
\end{abstract}

Results: The clinical outcome measures improved significantly in the three groups post-treatment $(p<0.05)$. However, patients in the DSPH group had more improvement in all outcome variables compared with the other two groups $(p<0.05)$ except for knee stiffness between DSPH and MSPH ( $p>0.05)$. No significant differences were observed in the mean changes in any of the outcome variables between MSPH and TUS therapy ( $p>0.05$ ).

Conclusion: Significant improvements in pain, stiffness, physical function, walking time and knee ROM were attained in all the three groups post-intervention. However, DSPH was found to be more effective compared with the other two groups. The degree of improvement in MSPH and TUS therapy was similar; MSPH was not superior to TUS in patients with knee OA.

Key words: Diclofenac sodium; knee joint osteoarthritis; methyl salicylate; phonophoresis; therapeutic ultrasound.
Amaç: Bu çalışmada diz osteoartritli (OA) hastalarda diklofenak sodyum fonoforezinin (DSPH), metil salisilat fonoforezinin (MSPH) ve geleneksel terapötik ultrasonun (TUS) etkinlikleri araştırıldı ve karşılaştırıldı.

Hastalar ve yöntemler: Bu çalışmaya Ekim 2008 - Haziran 2009 tarihleri arasında 45 hasta (8 erkek, 37 kadın; ort. yaş 57.5 yıl; dağılım 51-64 yıl) dahil edildi ve hastalar randomize şekilde üç gruba ayrıldı: DSPH, MSPH ve TUS. Birleştirici ortam olarak iki topikal ağrı kesici jelden biriyle hedef dize 1 $\mathrm{MHz}$ frekanslı ve 1 watt $/ \mathrm{cm}^{2}$ lik ultrason dalgaları uygulandı. Terapötik ultrason grubunda herhangi bir aktif farmakolojik ajan içermeyen akustik jel uygulandı. Üç gruptaki tüm hastalara 10 tedavi seansı uygulandı. Western Ontario McMaster Üniversitesi Osteoartrit İndeksi (WOMAC) skorları, 20 metre yürüme zamanı ve diz hareket aralığı (ROM) eşli t-testi ve variyans analizi (ANOVA) kullanılarak tedaviden önce ve sonra değerlendirildi.

Bulgular: Tedaviden sonra üç grupta da klinik sonuç ölçütlerinde anlamlı ölçüde iyileşme meydana geldi $(p<0.05)$. Bununla birlikte, diz sertliği açısından DSPH ile MSPH arasındaki fark istisnasıyla ( $p>0.05$ ), diğer iki grupla karşılaştırıldığında DSPH grubundaki hastalarda tüm sonuç değişkenlerinde daha fazla iyileşme görüldü $(p<0.05)$. Metil salisilat fonoforezin ile TUS terapisi arasında herhangi bir sonuç değişkenindeki ortalama değişiklik açısından hiçbir anlamlı farklılık gözlemlenmedi ( $p>0.05$ ).

Sonuç: Müdahalenin ardından üç grubun tümünde ağrı, fiziksel fonksiyon, yürüme zamanı ve diz ROM seviyesi açısından anlamlı iyileşmeler elde edildi. Bununla birlikte, diğer iki grupla karşılaştırıldığında DSPH'nin daha etkili olduğu tespit edildi. Metil salisilat fonoforezin ve TUS terapisiyle meydana gelen iyileşme seviyeleri benzerdi; diz OA'sı bulunan hastalarda MSPH, TUS'dan üstün değildi.

Anahtar sözcükler: Diklofenak sodyum; diz eklemi osteoartriti; metil salisilat; fonoforez; terapötik ultrason.

\section{Received: November 13, 2009 Accepted: April 12, 2010}

Correspondence: Sunday Akinbo, M.D. Department of Physiotherapy, College of Medicine, University of Lagos, Idi-Araba, Lagos, Nigeria.

Tel: 234-8037140973 e-mail: sonnyakinbo@yahoo.com

C2011 Turkish League Against Rheumatism. All rights reserved. 
Osteoarthritis (OA) is a disease chiefly involving deterioration of articular cartilage characterized clinically by a gradual development of pain, stiffness and loss of motion in synovial (weight-bearing) joints. It is the most common articular disease in the elderly and has variable clinical presentations which often carry significant disability. ${ }^{[1,2]}$ The therapeutic approach is mainly directed at the relief of symptoms. Treatment options, including pharmacological and non-pharmacological measures, have been recommended. ${ }^{[2,3]}$ Although non-steroidal anti-inflammatory drugs (NSAIDs) are widely used in the symptomatic treatment of OA, they are reported to be associated with hazards including gastrointestinal side effects particularly in the elderly. ${ }^{[3]}$ Other drug therapies are reported to have the same side effects as well. Physiotherapy is one of the recommended nonpharmacological management options. ${ }^{[2]}$

Physiotherapy (physical therapy) involves using physical modalities to produce therapeutic effects. The use of heat (superficial and deep), cold, pressure, light and electricity have been employed for thousands of years to accelerate healing and decrease pain in musculoskeletal disorders. ${ }^{[3,4]}$ Heat therapy is applied to obtain analgesia, decrease muscle spasm, increase collagen extensibility and accelerate metabolic processes. ${ }^{[3]}$ Other physiotherapy modalities commonly used includes hydrotherapy, LASER therapy, electrical stimulation, therapeutic ultrasound (TUS), iontophoresis, and phonophoresis. ${ }^{[3,5,6]}$

There are several methods of delivering medication transcutaneously. The most common is through intramuscular injection, but this is considered invasive. ${ }^{[6]}$ Alternative methods include the use of electromotive force to drive ions into the tissue called iontophoresis, and the use of mechanical force to deliver molecules referred to as phonophoresis. ${ }^{[7,8]}$ These two techniques have been established to be noninvasive and well-tolerated. Also, they have been shown to have no gastrointestinal side effects associated with most pain relieving drugs. ${ }^{[3,9-11]}$ Iontophoresis is a process that uses bipolar electric fields to propel ions across intact skin and into underlying tissues. ${ }^{[6,12]}$ The electrophysiological effects of this galvanic current ion delivery are analgesia and hyperaemia of the treated regions. $^{[12]}$

Phonophoresis $(\mathrm{PH})$ is a technique that employs the use of ultrasound waves to enhance percutaneous absorption of drug delivery similar to iontophoresis. ${ }^{[11,13]}$ Phonophoresis was first used to treat polyarthritis of the hand by delivery of hydrocortisone ointment into inflamed areas in $1954 .^{[14]}$ Since then it has been reported to be used in the treatment of various dermatological and musculoskeletal disorders. ${ }^{[13-16]}$

Previous studies have established the therapeutic effectiveness of various types of NSAIDs gel $\mathrm{PH}$ on both acute and chronic musculoskeletal pain and disorders. ${ }^{[17-20]}$ Because of the established efficacy of this modality, there are several ongoing studies with some controversies from previous studies. An example of this is the study of Kozanoglu et al. ${ }^{[18]}$ which reported that ibuprofen $\mathrm{PH}$ was not superior to conventional TUS in patients with knee OA and that both were found to be therapeutically effective. Also, there is a dearth of literature on the comparison of some of these analgesic gels via $\mathrm{PH}$ on degenerative diseases. This study, therefore, aimed to investigate and compare the therapeutic efficacy of diclofenac sodium PH (DSPH), methyl salicylate $\mathrm{PH}(\mathrm{MSPH})$ and conventional TUS therapy on patients with knee OA.

\section{PATIENTS AND METHODS}

The study was conducted at the Clinics of the Department of Physiotherapy, Lagos University Teaching Hospital, Lagos Nigeria. The local Ethics Committee approved the study protocol and all patients gave written informed consent.

\section{Subjects' selection}

A total of 52 subjects (11 males, 41 females; mean age 58 years; range 50 to 66 years) who were all out-patients with a diagnosis of knee OA referred by an orthopedic surgeon and rheumatologists for physiotherapy were recruited for the study. They were knee OA patients between October 2008 and June 2009 with the knee as the primary source of osteoarthritic pain. Also, all patients included in the study must have a minimum score of 25 on the Western Ontario McMaster University Osteoarthritis Index (WOMAC) total score. Patients were excluded from the study if they recently had dermatological problems, a skin allergy to topical diclofenac sodium or methyl salicylate, local ischeamic problems, secondary OA, open wounds around the target knee, or an intramuscular analgesic injection.

Patients were assessed by obtaining a detailed history and by carrying out a physical examination and radiographic assessment. Information relating to age, sex, weight, height, duration of knee pain and 
target knee the more symptomatic or painful knee (for patients with bilateral knee osteoarthritis) was also obtained. In patients with similar bilateral symptoms, the right knee was chosen as the target knee. Patients were questioned about past and present medications.

Of the 52 patients, seven were found ineligible for the study after screening and were therefore excluded. The eligible patients were randomly assigned to the three groups by one of the researchers who do not take part in the treatment afterward. Each group (DSPH, MSPH and TUS therapy) had 15 patients from the 45 eligible patients. However, only 40 patients ( 6 males, 34 females; mean age 57.5 years; range 51 to 64 years) completed the study. Reasons for withdrawal by the five subjects who did not complete the study are as given in Figure 1.

\section{Instrumentation}

- Therapeutic ultrasound machine ${ }^{\circledR}$ (Sonopuls 590 - Enraf Nonius)

- Bicycle ergometer ${ }^{\circledR}$ (Leader sport stationary bicycle)

- Electronic heat belt ${ }^{\circledR}$ (Flamingo Orthopaedic Heat Belt): An electronic heat therapy device in which heat is generated directly from electricity through embedded ring coils. It is very similar to the hydrocollator pack. It has the advantage of self-regulation by patients through a thermostat chip which allows for intensity control. Heat intensity can be regulated from 0 to 3 depending on patients' heat tolerance.

- (1\%) Diclofenac sodium gel preparation

- (15\%) Methyl salicylate cream preparation

- Aquasonic gel

- Drug weighing scale (Acculab Satorious Group)

- Bathroom weighing scale

- Height meter

- Stopwatch ${ }^{\circledR}$ (Sony Ericsson): Time required to walk a distance of 20-meters "as fast as possible" was measured with a stop-watch and reported in seconds.

- Goniometer $^{\circledR}$ (G 300 model): The range (flexion minus extension) of motion (ROM) of the target knee-measured with a long-arm universal goniometer.

- Methylated spirit and cotton wool

- WOMAC Questionnaire

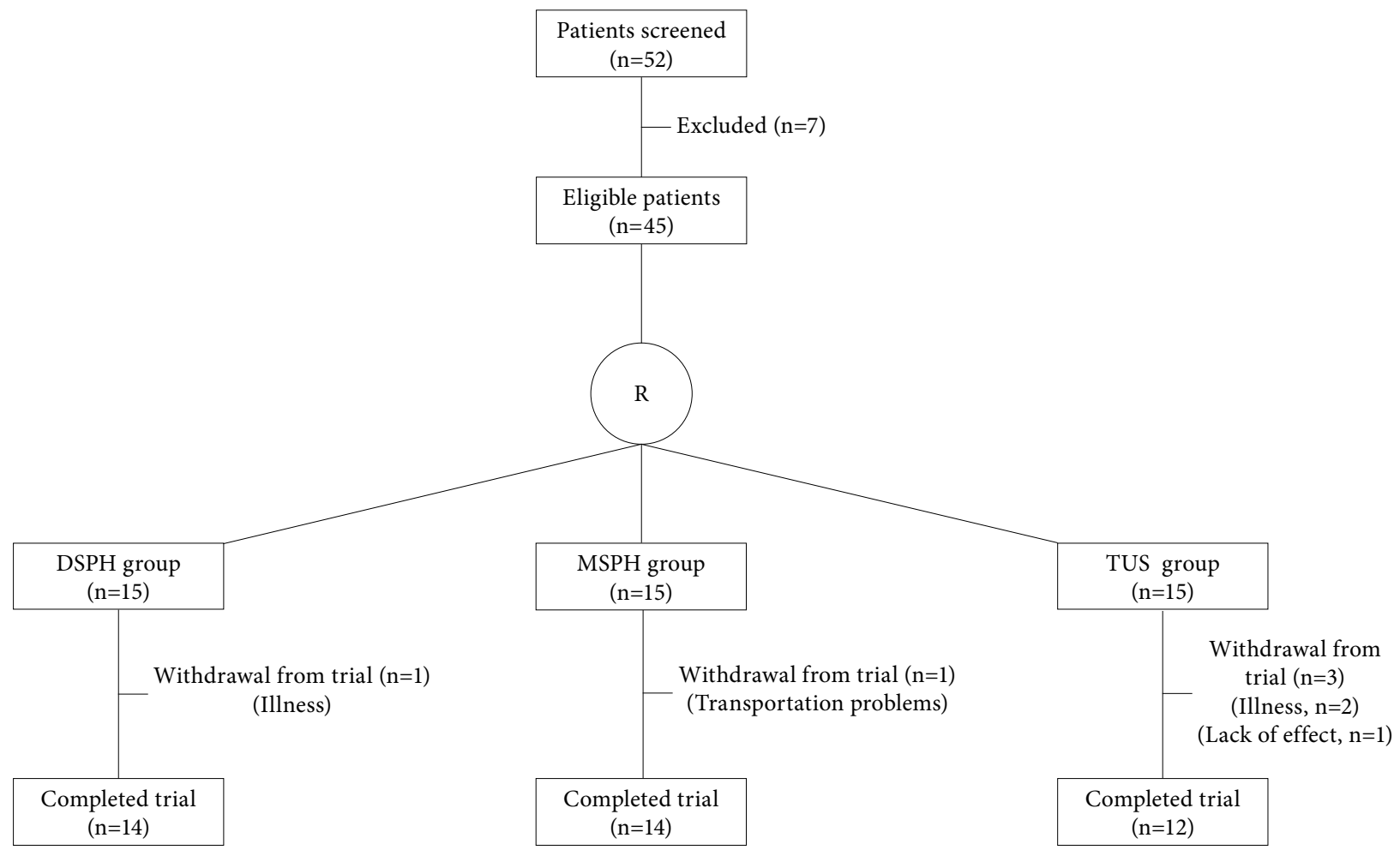

Figure 1. Flow of subjects through the study. R: Randomization; DSPH: Diclofenac sodium phonophoresis; MSPH: Methyl salicylate phonophoresis; TUS: Therapeutic ultrasound. 


\section{Therapeutic intervention}

The treatment was conducted five times a week (one treatment session/day) for two weeks, excluding weekends, for a total of 10 treatment sessions for each patient. Concomitant use of NSAIDs and analgesics in any form was not permitted throughout the study. Patients were put in a supine position with the knees extended. The target knee and transducer head of the ultrasound machine was cleansed with methylated spirit and cotton wool before treatment. An electronic heat belt was wrapped on the target knee for 15 minutes. Byl ${ }^{[21]}$ suggested that the skin should be pretreated with heat in order to maximize clinical effectiveness. This was then followed by the DSPH, MSPH or conventional TUS therapy depending on the patient's group.

In the DSPH and MSPH groups, a $5 \mathrm{~cm}$ long strip of topical gel containing 1\% diclofenac sodium (about $26 \mathrm{mg}$ diclofenac sodium) or 15\% methyl salicylate (about $395 \mathrm{mg}$ methyl salicylate) was applied from the tube over the target knee. Therapeutic ultrasound was then applied to the superomedial and lateral parts of the knee through the applicator head in circular movements. In the conventional TUS group, the skin was coated with an acoustic gel not containing any pharmacologically active substance. The transducer head was applied to the treatment region at right angles to ensure maximum absorption of the ultrasound energy. Continuous ultrasonic waves with $1 \mathrm{MHz}$ frequency and $1 \mathrm{watt} / \mathrm{cm}^{2}$ power were applied with a $4 \mathrm{~cm}$ diameter applicator. The treatment lasted five minutes for each session and used the treatment methods of Akinbo et al. ${ }^{[16]}$ and Kozanoglu et al. ${ }^{[18]}$ Remnant gel/cream on the target knee was wiped off post-treatment with cotton wool.

Low intensity ergometer cycling was used for all the patients as adjunct treatment for five minutes after each treatment session for the three groups. This is done to enhance joint ROM and accelerate blood flow to the affected joint. The post treatment protocol used by Akinbo et al. ${ }^{[16]}$ and Kozanoglu et al. ${ }^{[18]}$ was also adopted in which outcome data evaluation was performed two days after completion of the last session. This was to avoid the immediate effect of treatment on clinical outcome.

\section{Outcome measures}

The primary outcome measure of the study was total WOMAC scores at the end of the therapy (post-treatment) compared with baseline scores (pre- treatment). It probes clinically important, patientrelevant symptoms in the area of pain, stiffness and physical function in patients with OA of the hip or knee. The WOMAC questionnaire was used to measure pain, stiffness and physical function. WOMAC scores were recorded on a Likert scale of $0-4$ where $0=$ no pain/limitation; $1=$ mild pain/limitation; $2=$ moderate pain/limitation; $3=$ severe pain/limitation; and $4=$ very severe pain/limitation. Maximum scores for stiffness, pain and physical function were 8,20 and 68 respectively with a total score of $96 .^{[22]}$

\section{Statistical analysis}

Statistical Package for Social Science (SPSS Inc., Chicago, Illinois, USA) 15.0 version for Windows package program was used to analyze data. Demographic and quantitative data were expressed as mean \pm standard deviation (SD) and confidence interval (CI). Paired sample t-test was used to compare the baseline/pretreatment and posttreatment changes in outcome variables in each group. One-way analysis of variance (ANOVA) was used to detect any statistically significant differences in the (improvement) changes between the three groups. A post-hoc evaluation of ANOVA using the least significant difference (LSD) was carried out to compare the mean changes between the three groups in order to detect where statistical differences existed and which treatment was statistically more effective. All statistical tests were two-sided and performed at the 0.05 level of significance (i.e. $\mathrm{p}<0.05$ ).

\section{RESULTS}

Baseline characteristics of the patients are given in Table 1. The right knee was the target knee for most of the patients accounting for 29 out of 40 cases. Comparison of baseline mean values using analysis of variance revealed that there were no significant differences in baseline characteristics in the groups with respect to age, gender, target knee, body mass index (BMI), 20 meters walking time, ROM degrees and WOMAC scores ( $\mathrm{p}>0.05$ in all cases).

The clinical outcome variables after 10 treatment sessions ( 2 weeks) are presented in Table 2. There were significant differences in mean values of all primary and secondary outcome measures pre and post-intervention $(\mathrm{p}<0.05)$ in all the groups.

Statistically significant differences existing among the treatment groups post-intervention using ANOVA, and these are shown in Table 3. The result reveals 


\begin{tabular}{|c|c|c|c|c|c|}
\hline \multirow[t]{2}{*}{ Characteristics } & \multirow{2}{*}{$\frac{\text { DSPH group }}{\text { Mean } \pm \text { SD }}$} & \multirow{2}{*}{$\frac{\text { MSPH group }}{\text { Mean } \pm \text { SD }}$} & \multirow{2}{*}{$\frac{\text { TUS group }}{\text { Mean } \pm \text { SD }}$} & \multirow[t]{2}{*}{ F-values } & \multirow[t]{2}{*}{$p$} \\
\hline & & & & & \\
\hline Age (year) & $64.29 \pm 9.83$ & $62.50 \pm 10.28$ & $64.92 \pm 10.52$ & 1.308 & 0.283 \\
\hline Body mass index $\left(\mathrm{kg} / \mathrm{m}^{2}\right)$ & $30.83 \pm 3.90$ & $31.79 \pm 3.97$ & $30.42 \pm 3.70$ & 0.442 & 0.646 \\
\hline 20 meters walking time & $18.08 \pm 3.54$ & $17.96 \pm 2.341$ & $7.61 \pm 2.77$ & 0.089 & 0.915 \\
\hline ROM in degree & $107.80 \pm 12.41$ & $111.07 \pm 11.18$ & $108.17 \pm 10.31$ & 0.343 & 0.712 \\
\hline \multicolumn{6}{|l|}{ WOMAC scores } \\
\hline Pain & $10.29 \pm 2.67$ & $10.83 \pm 2.44$ & $10.83 \pm 2.44$ & 1.304 & 0.284 \\
\hline Stiffness & $3.43 \pm 1.56$ & $3.57 \pm 2.07$ & $3.2 \pm 2.34$ & 0.084 & 0.920 \\
\hline Physical function & $31.36 \pm 6.99$ & $26.64 \pm 7.82$ & $25.83 \pm 5.75$ & 2.473 & 0.098 \\
\hline Total & $45.07 \pm 9.36$ & $39.57 \pm 9.26$ & $40.33 \pm 5.90$ & 1.720 & 0.193 \\
\hline
\end{tabular}

significant differences among the three groups for both primary and secondary outcome measures, except for stiffness, in the WOMAC scores.

A post-hoc analysis of least significant difference (LSD) was carried out to find out where significant differences existed among the three groups. Statistically significant differences regarding improvement changes in primary and secondary outcome measures were found between DSPH and MSPH in all variables $(\mathrm{p}<0.05)$ except stiffness. The mean change in pain was statistically significantly superior in DSPH compared with MSPH. For the secondary variables, DSPH treatment was also superior to MSPH (Table 4).
The differences regarding improvement changes in primary and secondary outcome measures between groups DSPH and TUS are also reveled in Table 4 . Statistically significant differences regarding improvement changes in primary and secondary outcome measures were found to exist between the groups in all outcome variables; the DSPH was superior compared with the conventional TUS $(\mathrm{p}<0.05)$.

No statistically significant differences were observed regarding changes in primary and secondary outcome measures between the MSPH and conventional TUS ( $>0.05)$. Both groups exhibited similar treatment efficacy (Table 4).

Table 2. Analysis of clinical outcome measures of patients in the three groups pre- and post-intervention

\begin{tabular}{|c|c|c|c|c|c|c|}
\hline \multirow[t]{3}{*}{ Variables } & \multicolumn{3}{|c|}{ Primary outcome scores (WOMAC) } & \multicolumn{3}{|c|}{ Secondary outcome scores } \\
\hline & Pain & Stiffness & Physical function & Total & $20 \mathrm{~m} \mathrm{WT}$ & $\mathrm{ROM}$ \\
\hline & $\overline{M e a n} \pm$ SD & $\overline{M e a n} \pm$ SD & Mean \pm SD & Mean \pm SD & $\overline{M e a n} \pm$ SD & Mean \pm SD \\
\hline \multicolumn{7}{|l|}{ DSPH group } \\
\hline Pre-treatment & $10.29 \pm 2.67$ & $3.43 \pm 1.56$ & $31.36 \pm 6.99$ & $45.07 \pm 9.36$ & $18.08 \pm 3.54$ & $107.79 \pm 12.41$ \\
\hline Post-treatment & $2.93 \pm 1.94$ & $1.07 \pm 0.83$ & $10.93 \pm 3.77$ & $14.93 \pm 5.57$ & $15.56 \pm 3.45$ & $115.79 \pm 11.68$ \\
\hline t-values & 10.392 & 6.333 & 13.268 & 14.852 & 10.793 & 11.776 \\
\hline $\mathrm{p}$-values & $<0.001^{*}$ & $<0.001^{\star}$ & $<0.001^{*}$ & $<0.001^{*}$ & $<0.001^{\star}$ & $<0.001^{*}$ \\
\hline \multicolumn{7}{|l|}{ MSPH group } \\
\hline Pre-treatment & $9.07 \pm 3.36$ & $3.57 \pm 2.07$ & $26.64 \pm 7.82$ & $39.57 \pm 9.26$ & $17.96 \pm 2.34$ & $111.07 \pm 11.18$ \\
\hline Post-treatment & $4.86 \pm 2.45$ & $1.71 \pm 1.14$ & $17.71 \pm 8.16$ & $24.29 \pm 9.04$ & $16.31 \pm 2.30$ & $116.36 \pm 11.18$ \\
\hline t-values & 7.087 & 5.377 & 5.339 & 7.456 & 12.355 & 12.837 \\
\hline p-values & $<0.001^{\star}$ & $<0.001^{\star}$ & $<0.001^{\star}$ & $<0.001^{\star}$ & $<0.001^{\star}$ & $<0.001^{\star}$ \\
\hline \multicolumn{7}{|l|}{ TUS group } \\
\hline Pre-treatment & $10.83 \pm 2.44$ & $3.25 \pm 2.34$ & $25.83 \pm 5.75$ & $40.33 \pm 5.10$ & $17.61 \pm 2.77$ & $108.17 \pm 10.31$ \\
\hline Post-treatment & $7.33 \pm 2.19$ & $2.08 \pm 1.73$ & $18.83 \pm 7.03$ & $28.17 \pm 7.92$ & $16.38 \pm 2.76$ & $113.42 \pm 9.95$ \\
\hline t-values & 6.132 & 4.311 & 8.042 & 8.742 & 5.337 & 7.525 \\
\hline p-values & $<0.001^{*}$ & $<0.001^{\star}$ & $<0.001^{\star}$ & $<0.001^{\star}$ & $<0.001^{\star}$ & $<0.001^{\star}$ \\
\hline
\end{tabular}




\begin{tabular}{|c|c|c|c|c|c|}
\hline \multirow[t]{2}{*}{ Outcome measures } & DSPH group & MSPH group & TUS group & F-values & $p$ \\
\hline & Mean \pm SD & Mean \pm SD & $\overline{\text { Mean } \pm \text { SD }}$ & & \\
\hline \multicolumn{6}{|l|}{ Primary outcome measure } \\
\hline \multicolumn{6}{|l|}{ WOMAC scores } \\
\hline Pain & $7.36 \pm 2.65$ & $4.21 \pm 2.22$ & $3.50 \pm 1.98$ & 10.530 & $<0.001^{\star}$ \\
\hline Stiffness & $2.36 \pm 1.39$ & $1.86 \pm 1.29$ & $1.17 \pm 0.94$ & 3.009 & 0.062 \\
\hline Physical function & $20.43 \pm 5.76$ & $8.93 \pm 6.26$ & $7.00 \pm 3.02$ & 6.379 & $0.004^{\star}$ \\
\hline Total & $30.15 \pm 7.59$ & $15.29 \pm 7.67$ & $12.17 \pm 4.82$ & 25.914 & $<0.001^{\star}$ \\
\hline \multicolumn{6}{|l|}{ Secondary outcome measure } \\
\hline 20 meters walking time & $2.51 \pm 0.87$ & $1.66 \pm 0.50$ & $1.23 \pm 0.83$ & 10.378 & $<0.001^{\star}$ \\
\hline Range of motion & $8.00 \pm 2.54$ & $5.29 \pm 1.54$ & $5.25 \pm 2.42$ & 7.010 & $0.003^{\star}$ \\
\hline
\end{tabular}

\section{DISCUSSION}

In this randomized controlled study, marked improvements in clinical outcomes were obtained with DSPH, MSPH and conventional TUS in patients with knee OA. All primary and secondary outcome measures of the study improved significantly postintervention. This result corroborates previous studies concerning the efficacy of $\mathrm{PH}$ and TUS in relieving pain, improving function and enhancing healing in musculoskeletal disorders. ${ }^{[16-20]}$ The reduction in pain and improved functional activity level could be a result of the local thermal and mechanical effects of TUS and the analgesic gels on tissues surrounding the painful knee.

The use of $\mathrm{PH}$ in clinical practice has been reported to represent up to $30 \%$ of the physiotherapy visits in some centers. ${ }^{[23,24]}$ Approximately $75 \%$ of the studies reported by Byl ${ }^{[21]}$ indicated some level of effectiveness of TUS as an enhancer of topically applied medications.

Diclofenac sodium and MS gels/creams are widely used in physiotherapy clinics and readily prescribed to patients with musculoskeletal disorders. Cross et al. ${ }^{[2]}$ reported that cutaneous microdialysis to determine the direct local penetration of topically applied formulation containing MS was found to be approximately 30 -fold higher than the plasma concentrations. It was also reported that the topical application (through massage) of DS over an inflamed joint resulted in synovial fluid drug concentration which exceeded systemic plasma concentrations suggesting a direct penetration of the drug into the synovial fluid of the joint. ${ }^{[25]}$

The present study proposed that $\mathrm{PH}$ would enhance penetration of DS and MS to patients' knees resulting in therapeutic benefits compared to those of conventional TUS. However, only DSPH was found to have better effects compared with conventional TUS. MSPH was not found to be significantly superior to conventional TUS. Improvement in WOMAC scores for DSPH was significantly better than the MSPH almost doubling that of conventional TUS. This may be attributed to the transdermal drug delivery potential of DS through $\mathrm{PH}$. Heating the tissue through ultrasound waves increases the kinetic energy of drug molecules in the cell membrane. Ultrasound has also been found to dilate points of entry of topical drugs, such as the hair follicles and the sweat glands, thereby increasing circulation to the area sonicated. ${ }^{[24]}$ These physiological changes are said to enhance the opportunity for drug molecules to diffuse through the stratum corneum and be collected by the capillary network in the dermis and underlying tissues. The mechanical characteristics of the sound wave also enhance drug diffusion by oscillating the cells at high speed, changing the resting potential of the cell membrane and potentially disrupting the cell membrane of some of the cells in the area. ${ }^{[24]}$

The superiority of DSPH over MSPH observed in this study could be as a result of the differences that exist in the chemical properties of DS and MS with respect to their permeability through ultrasound waves to the tissue. The depth of penetration of a drug is said to depend on the the drug's mass (which is inversely proportional to its molecular weight). ${ }^{[26]}$ Diclofenac sodium $(318.1 \mathrm{~g} / \mathrm{mol})$ has a higher molecular weight than MS $(152.2 \mathrm{~g} / \mathrm{mol})$, hence a lower drug mass and, therefore, a better permeability through the ultrasound waves. ${ }^{[26]}$ The aforementioned reasons may explain why patients in the DSPH group recorded more improvement compared with those in MSPH group. 
Table 4. Post-hoc analysis of changes in clinical outcome measures between DSPH \& MSPH, DSPH \& TUS and MSPH \& TUS

\begin{tabular}{|c|c|c|c|}
\hline \multirow[t]{3}{*}{ Outcome measures } & \multicolumn{2}{|c|}{ Post-hoc analysis between DSPH and MSPH groups } & \multirow{3}{*}{$p$} \\
\hline & DSPH group & MSPH group & \\
\hline & Mean \pm SD & Mean \pm SD & \\
\hline \multicolumn{4}{|l|}{ Primary outcome measure } \\
\hline \multicolumn{4}{|l|}{ WOMAC scores } \\
\hline Pain & $7.36 \pm 2.65$ & $4.21 \pm 2.22$ & $0.001^{\star}$ \\
\hline Stiffness & $2.36 \pm 1.39$ & $1.86 \pm 1.29$ & 0.292 \\
\hline Physical function & $20.43 \pm 5.76$ & $8.93 \pm 6.26$ & $0.004^{*}$ \\
\hline Total & $30.15 \pm 7.59$ & $15.29 \pm 7.67$ & $<0.001^{\star}$ \\
\hline \multicolumn{4}{|l|}{ Secondary outcome measure } \\
\hline 20 meters walking time & $2.51 \pm 0.87$ & $1.66 \pm 0.50$ & $0.004^{*}$ \\
\hline Range of motion & $8.00 \pm 2.54$ & $5.29 \pm 1.54$ & $0.002^{\star}$ \\
\hline \multirow[t]{3}{*}{ Outcome measures } & \multicolumn{2}{|c|}{ Post-hoc analysis between DSPH and TUS groups } & \multirow{3}{*}{$p$} \\
\hline & DSPH group & TUS group & \\
\hline & Mean \pm SD & Mean \pm SD & \\
\hline \multicolumn{4}{|l|}{ Primary outcome measure } \\
\hline \multicolumn{4}{|l|}{ WOMAC scores } \\
\hline Pain & $7.36 \pm 2.65$ & $3.50 \pm 1.98$ & $<0.001^{\star}$ \\
\hline Stiffness & $2.36 \pm 1.39$ & $1.17 \pm 0.94$ & $0.019^{*}$ \\
\hline Physical function & $20.43 \pm 5.76$ & $7.00 \pm 3.02$ & $0.005^{\star}$ \\
\hline Total & $30.15 \pm 7.59$ & $12.17 \pm 4.82$ & $<0.001^{\star}$ \\
\hline \multicolumn{4}{|l|}{ Secondary outcome measure } \\
\hline 20 meters walking time & $2.51 \pm 0.87$ & $1.23 \pm 0.83$ & $<0.001^{\star}$ \\
\hline Range of motion & $8.00 \pm 2.54$ & $5.25 \pm 2.42$ & $0.003^{*}$ \\
\hline \multirow[t]{3}{*}{ Outcome measures } & \multicolumn{2}{|c|}{ Post-hoc analysis between MSPH and TUS groups } & \multirow{3}{*}{$p$} \\
\hline & MSPH group & TUS group & \\
\hline & Mean \pm SD & Mean \pm SD & \\
\hline \multicolumn{4}{|l|}{ Primary outcome measure } \\
\hline \multicolumn{4}{|l|}{ WOMAC scores } \\
\hline Pain & $4.21 \pm 2.22$ & $3.50 \pm 1.98$ & 0.438 \\
\hline Stiffness & $1.86 \pm 1.29$ & $1.17 \pm 0.94$ & 0.164 \\
\hline Physical function & $8.93 \pm 6.26$ & $7.00 \pm 3.02$ & 0.979 \\
\hline Total & $15.29 \pm 7.67$ & $12.17 \pm 4.82$ & 0.259 \\
\hline \multicolumn{4}{|l|}{ Secondary outcome measure } \\
\hline 20 meters walking time & $1.66 \pm 0.50$ & $1.23 \pm 0.83$ & 0.149 \\
\hline Range of motion & $5.29 \pm 1.54$ & $5.25 \pm 2.42$ & 0.967 \\
\hline
\end{tabular}

A previous study by Klaiman et al. ${ }^{[27]}$ on the efficacy of fluocinonide PH versus TUS in subjects with soft tissue injuries found no difference in pain level and pressure tolerance among groups. Similarly, Ciccone et al. ${ }^{[17]}$ evaluated the efficacy of trolamine salicylate $\mathrm{PH}$ and ultrasound therapy on delayed onset muscle soreness. They reported that topically applied salicylates $(10 \%$, trolamine salicylate) via $\mathrm{PH}$ significantly reduced muscle soreness. Cabak et al. ${ }^{[20]}$ also reported that ketoprofen $\mathrm{PH}$ was significantly more effective than conventional TUS in the management of patients with epocondylopathy of the elbow. Most of these findings corroborate the present study.

It is possible that the application of heat before treatment and ergometer therapy post treatment may have influenced this study positively. The treatment protocol was set up in this manner to enhance drug delivery to peri-articular structures of the knee as reported by $\mathrm{Byl}^{[21]}$ and Yang et al. ${ }^{[28]}$ To avoid the 
influence of immediate thermal effect on the present study, outcome data was collected two days after the completion of the last treatment session adopting the protocol of Akinbo et al. ${ }^{[16]}$

In conclusion, significant improvements in pain, stiffness, physical function, walking time and knee ROM were attained in all the three groups. The findings of this study showed that DSPH, MSPH and conventional TUS were effective in relieving symptoms in patients with knee OA. However, DSPH was found to be more therapeutically effective compared with the other two methods. Furthermore, the degree of improvement in MSPH and conventional TUS therapy was similar, MSPH was not superior to TUS in alleviating clinical symptoms in patients with knee OA.

\section{Declaration of conflicting interests}

The authors declared no conflicts of interest with respect to the authorship and/or publication of this article.

\section{Funding}

The authors received no financial support for the research and/or authorship of this article.

\section{REFERENCES}

1. Easton BT. Evaluation and treatment of the patient with osteoarthritis. J Fam Pract 2001;50:791-7.

2. Recommendations for the medical management of osteoarthritis of the hip and knee: 2000 update. American College of Rheumatology. Subcommittee on Osteoarthritis Guidelines. Arthritis Rheum 2000;43:1905-15.

3. Hochberg MC. Nutritional supplements for knee osteoarthritis-still no resolution. N Engl J Med 2006;354:858-60.

4. Loeser RF Jr. Aging and the etiopathogenesis and treatment of osteoarthritis. Rheum Dis Clin North Am 2000;26:547-67.

5. Yang JH, Kim DK, Yun MY, Kim TY, Shin SC. Transdermal delivery system of triamcinolone acetonide from a gel using phonophoresis. Arch Pharm Res 2006;29:412-7.

6. Banga AK, Chien YW. Iontophoretic delivery of drugs: fundamental, developmental and biomedical applications. J Controlled Release 1988;17:1-24.

7. NirschlRP,RodinDM,OchiaiDH,Maartmann-MoeC;DEXAHE-01-99 Study Group. Iontophoretic administration of dexamethasone sodium phosphate for acute epicondylitis. A randomized, double-blinded, placebo-controlled study. Am J Sports Med 2003;31:189-95.

8. Hasson SH, Henderson GH, Daniels JC, Schieb DA. Exercise training and dexamethasone iontophoresis in rheumatoid arthritis: a case study. Physiother Can 1991;43:11-4.
9. Anderson CR, Morris RL, Boeh SD, Panus PC, Sembrowich WL. Effects of iontophoresis current magnitude and duration on dexamethasone deposition and localized drug retention. Phys Ther 2003;83:161-70.

10. Cagnie B, Vinck E, Rimbaut S, Vanderstraeten G. Phonophoresis versus topical application of ketoprofen: comparison between tissue and plasma levels. Phys Ther 2003;83:707-12.

11. Kassan DG, Lynch AM, Stiller MJ. Physical enhancement of dermatologic drug delivery: iontophoresis and phonophoresis. J Am Acad Dermatol 1996;34:657-66.

12. Panus PC, Ferslew KE, Tober-Meyer B, Kao RL. Ketoprofen tissue permeation in swine following cathodic iontophoresis. Phys Ther 1999;79:40-9.

13. Li LC, Scudds RA, Heck CS, Harth M. The efficacy of dexamethasone iontophoresis for the treatment of rheumatoid arthritic knees: a pilot study. Arthritis Care Res 1996;9:126-32.

14. Tyle P, Agrawala P. Drug delivery by phonophoresis. Pharm Res 1989;6:355-61.

15. Kamenskaia NS, Fedorova NE. The therapeutic use of iodide-bromide-sodium chloride baths combined with hydrocortisone phonophoresis in patients with osteoarthrosis and gout. Vopr Kurortol Fizioter Lech Fiz Kult 1990;6:47-50.

16. AkinboSR, Aiyejusunle CB, AkinyemiOA, Adesegun SA, Danesi MA. Comparison of the therapeutic efficacy of phonophoresis and iontophoresis using dexamethasone sodium phosphate in the management of patients with knee osteoarthritis. Niger Postgrad Med J 2007;14:190-4.

17. Ciccone CD, Leggin BG, Callamaro JJ. Effects of ultrasound and trolamine salicylate phonophoresis on delayed-onset muscle soreness. Phys Ther 1991;71:666-75.

18. Kozanoglu E, Basaran S, Guzel R, Guler-Uysal F. Short term efficacy of ibuprofen phonophoresis versus continuous ultrasound therapy in knee osteoarthritis. Swiss Med Wkly 2003;133:333-8.

19. Vlak T. Comparative study of the efficacy of ultrasound and sonophoresis in the treatment of painful shouder syndrome. Reumatizam 1999;46:5-11.

20. Cabak A, Maczewska M, Lyp M, Dobosz J, Gasiorowska U. The effectiveness of phonophoresis with ketoprofen in the treatment of epicondylopathy. Ortop Traumatol Rehabil 2005;7:660-5.

21. Byl NN. The use of ultrasound as an enhancer for transcutaneous drug delivery: phonophoresis. Phys Ther 1995;75:539-53.

22. Bellamy N. WOMAC Osteoarthritis index, user guide. Version VI. Queensland Australia; 2003.

23. Huang MH, Lin YS, Lee CL, Yang RC. Use of ultrasound to increase effectiveness of isokinetic exercise for knee osteoarthritis. Arch Phys Med Rehabil 2005;86:1545-51.

24. Cross SE, Anderson C, Roberts MS. Topical penetration of commercial salicylate esters and salts using human isolated skin and clinical microdialysis studies. Br J Clin Pharmacol 1998;46:29-35. 
25. Radermacher J, Jentsch D, Scholl MA, Lustinetz T, Frölich JC. Diclofenac concentrations in synovial fluid and plasma after cutaneous application in inflammatory and degenerative joint disease. Br J Clin Pharmacol 1991;31:537-41.

26. Srbely JZ. Ultrasound in the management of osteoarthritis: part I: a review of the current literature. J Can Chiropr Assoc 2008;52:30-7.
27. Klaiman MD, Shrader JA, Danoff JV, Hicks JE, Pesce WJ, Ferland J. Phonophoresis versus ultrasound in the treatment of common musculoskeletal conditions. Med Sci Sports Exerc 1998;30:1349-55.

28. Yang JH, Kim DK, Yun MY, Kim TY, Shin SC. Transdermal delivery system of triamcinolone acetonide from a gel using phonophoresis. Arch Pharm Res 2006;29:412-7. 